\title{
Composition, density and biomass of fish community from the surf zone as a function of the lunar cycle at Miramar Beach in Cabedelo, Paraíba
}

\author{
Willy Vila Nova Pessoa ${ }^{1}$, Jonas de Assis Almeida Ramos ${ }^{2}$ and \\ Paulo Guilherme Vasconcelos de Oliveira ${ }^{3}$
}

The influence of the moon cycles on the ichthyofauna has been little studied in the surf zone. In this study, the number of species, density and biomass were evaluated as a function of the moon. A total of 49 species distributed in 24 families were captured in two areas of Miramar beach. The mean density was significant high in the weaning and low in the new moon, while density and biomass together showed differences for areas. The most abundant species were Anchoa tricolor and Trachinotus falcatus (new moon), and Anchovia clupeoides showed significant differences in the waning moon. The RDA indicates that turbidity influenced significantly the presence of two species group. The group I were represented by Stellifer brasiliensis, Trachinotus goodei, A. clupeoides, Chilomycterus spinosus and Conodon nobilis that occurred on the waning and new phases in both areas, while the group II were represented by Polydactylus virginicus and Haemulopsis corvinaeformis in the full moon. The surf zones may also be strongly governed by the lunar phases. Therefore, the results found in this study, showed that the biological interactions between the species with turbidity and moon might explain the density and biomass variations for some species in the surf zone.

Keywords: Juveniles, Marine ecology, Marine fishes, Spatiotemporal pattern, Seine net.

A influência das fases lunares sobre a ictiofauna tem sido pouco estudada na zona de arrebentação. Nesse estudo, foram avaliadas, o número de espécies, densidade e a biomassa da ictiofauna em função da lua. Foram capturadas 49 espécies distribuídas em 24 famílias em duas áreas na Praia de Miramar. A densidade foi significativamente elevada nas luas minguante e nova. Além disso, a densidade e biomassa juntas mostraram diferenças entre as áreas. As espécies mais abundantes na lua nova foram Anchoa tricolor e Trachinotus falcatus, e Anchovia clupeoides teve uma maior abundancia na lua minguante. $\mathrm{O}$ RDA, indicou que a turbidez influenciou significativamente a presença de dois grupos distintos. O grupo I, representado por Stellifer brasiliensis, Trachinotus goodei, A. clupeoides, Chilomycterus spinosus e Conodon nobilis estiveram presentes nas luas minguante e nova em ambas as áreas, e o grupo II, representado por Polydactylus virginicus e Haemulopsis corvinaeformis na lua cheia. As zonas de arrebentação também podem ser reguladas fortemente pelas fases lunares. Os resultados mostraram que as interações biológicas entre as espécies com a turbidez e as fases lunares podem explicar as variações de densidade e biomassa para algumas espécies na zona de arrebentação.

Palavras-chave: Ecologia marinha, Juvenis, Peixes marinhos, Padrão espaço-temporal, Rede de arrasto.

\section{Introduction}

The behavior and abundance of various animals in nature change as a function of lunar cycles and tidal regimes (McDowall, 1969). These factors may be influence of biological processes important to fish life (Taylor, 1984). The lunar cycles and their effect on fish have been investigated by several authors (Quin, Kojis, 1981; Goldman et al., 1983; Rooker, Dennis, 1991; Laroche et al., 1997; deBruyn, Meeuwing, 2001, Das et al., 2005), although research involving lunar and tidal cycles is important in understanding the larvae behavior, juveniles and adults of fish and marine invertebrates (Ramos et al., 2011; Lacerda et al., 2014, Lima et al., 2016). Additionally, studies that correlate the lunar cycle to the composition, abundance and biomass of the ichthyofauna in tropical regions are limited.

\footnotetext{
${ }^{1}$ Instituto Federal de Educação, Ciência e Tecnologia de Pernambuco - Campus Vitória de Santo Antão, Propriedade Terra Preta, s/n, Zona Rural, 55600-000 Vitória de Santo Antão, PE, Brazil. willy.vilanova@vitoria.ifpe.edu.br, Ohttps://orcid.org/0000-0002-5310-807X (corresponding author)

${ }^{2}$ Grupo de Ecologia de Ecossistemas Marinhos, Laboratório de Oceanografia, Instituto Federal de Educação, Ciência e Tecnologia da Paraíba, Campus Cabedelo, Rua Santa Rita de Cássia, 1900, Jardim Camboinha, 58103-772 Cabedelo, PB, Brazil. jonas.ramos@ifpb.edu.br, Ohttps://orcid.org/0000-0001-6228-2830

${ }^{3}$ Departamento de Pesca e Aquicultura, Laboratório de Etologia de Peixes, Universidade Federal Rural de Pernambuco, Av. Dom Manoel de Medeiros, s/n, Dois Irmãos, 52171-900 Recife, PE, Brazil. oliveirapg@hotmail.com, Ohttps://orcid.org/https://orcid.org/0000-0001-7697-2111
} 
The surf zones suffer significant impacts, due to, the exploitation of natural resources, including the ichthyofauna of commercial importance for artisanal fisheries. This zone acts as a nursery, feeding and refuge grounds for juveniles fish (Menegassi del Favero, Dias, 2013; Lacerda et al., 2014; Ramos et al., 2016); and at the same time, are vulnerable habitats to stressful environmental impacts on the living or passing ichthyofauna. These areas act as a migration route for larvae and juveniles, especially in environments close to estuaries (Cowley et al., 2001; Watt-Pringle, Strydom, 2003) and also have a high ecological value, especially for juvenile fish species (Gaelzer, Zalmon, 2003).

Abiotic factors affect the distribution and abundance of fish, such as: temperature (Harrison, Whitfield, 2006), salinity (Barletta et al., 2005), turbidity and salinity (Menegassi del Favero, Dias, 2013), tide height (Laroche et al., 1997), and exposure to the waves (Romer, 1990; Gaelzer, Zalmon, 2003, Vasconcelos et al., 2007, Inui et al., 2010, Oliveira, Pessanha, 2014). Abiotic processes can result in stress to ichthyofauna to the point of causing leakage or substantial behavioral changes, especially in habitats where situations change during a short timescale (i.e during lunar cycles) (Lacerda et al., 2014). Seasonality in the marine environment may interfere with the pattern of the ichthyofaunistic community (Santana et al., 2013) and the bioecological processes of predation, competition, and recruitment may also determine the structure of these communities in the surf zones (Oliveira, Pessanha, 2014). This study aimed to describe and evaluate the composition, density and biomass of the ichthyofauna of the surf zone on a tropical beach on the shore of the Paraíba River mouth (Cabedelo city, Brazil), in relation to the different lunar phases and beach areas.

\section{Material and Methods}

Place of study. The sampled specimens were captured at Miramar beach in Cabedelo, Paraíba, northeast Brazil (Latitude: 06 57'52, 92 “'S, Longitude: 03450'01, 02”) (Fig. 1). The collection area is located close to the Paraíba River mouth covering a sliver of beach with $1.5 \mathrm{~km}$ extension to the Cabedelo dam. In this section, two areas were chosen, named as A1 and A2. In the area A1, has a greater influence of waves near the dam of Cabedelo was observed. Area A2 is further away from the estuary, with lower incidence of waves and clear presence of tourists, as well as, business establishments.

Sampling. Samples were collected weekly using a beach seine net, with three replicates (hauls) in each area (A1 and A2) during the lunar cycle of May 2014. Then, to ensure the robustness of analysis, the same sample design was repeated during the lunar cycle of June 2014, accounting 48 samples. The net was $15 \mathrm{~m}$ long, variable height 1.8 to $2.2 \mathrm{~m}$, fixed open of $7 \mathrm{~m}$ and with $5 \mathrm{~mm}$ mesh size nodes. Hauls were performed during day light, between the period of 2 hours before and 2 hours after the low tide, according to methodology of Able et al. (2013). Hauls effort had five minutes duration, conducted parallel to the coast and had initial and final position recorded by GPS system (Global Positioning System GARMIN, eTrex Vista ${ }^{\circledR}$ HCX) (Lacerda et al., 2014).

To compute swept area (SA), the length of path was obtained from GPS, then it was used in the following equation: $\mathrm{SA}=\mathrm{D} \times \mathrm{ARp}$, where: $\mathrm{D}$ is the distance in meters traversed by the trawl; ARp is the standard network aperture (set at 7 meters), which is equal to the width of the network path (Sparre, Venema, 1998). The capture per unit area (CPUA) was used to calculate the density (ind.ha ${ }^{-1}$ ) and biomass (g.ha${ }^{1}$ ), dividing the catches (number and mass of individuals) by the area surveyed according to Sparre, Venema (1998).

Before each sample, the water temperature $\left({ }^{\circ} \mathrm{C}\right)$, salinity (ITREF10, Intrutemp $\AA$ ), turbidity in NTU (TB-1000, Tecnopon ${ }^{\circledR}$ ), conductivity in $\mathrm{mS}$ (milliSiemens) with mCA150 model (Tecnopon $\left.{ }^{\circledR}\right)$ and the $\mathrm{pH}$ of water (mPA-210, Tecnopon $\left.{ }^{\circledR}\right)$, were measured from half-water, exactly at the points marked on the GPS of each trawl in the surf zone. After capture, the fish were properly labeled, kept in plastic bags and stored on ice. In the laboratory, all fish were identified, counted and weighed $(\mathrm{g})$ in $0.0001 \mathrm{~g}$ precision balance, and the measured pattern length (SL) and total (TC) in millimeters. For the identification of the species, specialized bibliographies have been used (Figueiredo, 1977; Figueiredo, Menezes, 1978, 1980, 2000; Carpenter, 2002a; Carpenter, 2002b; Eschmeyer, 2016; Richards, 2006; Froese, Pauly, 2016).

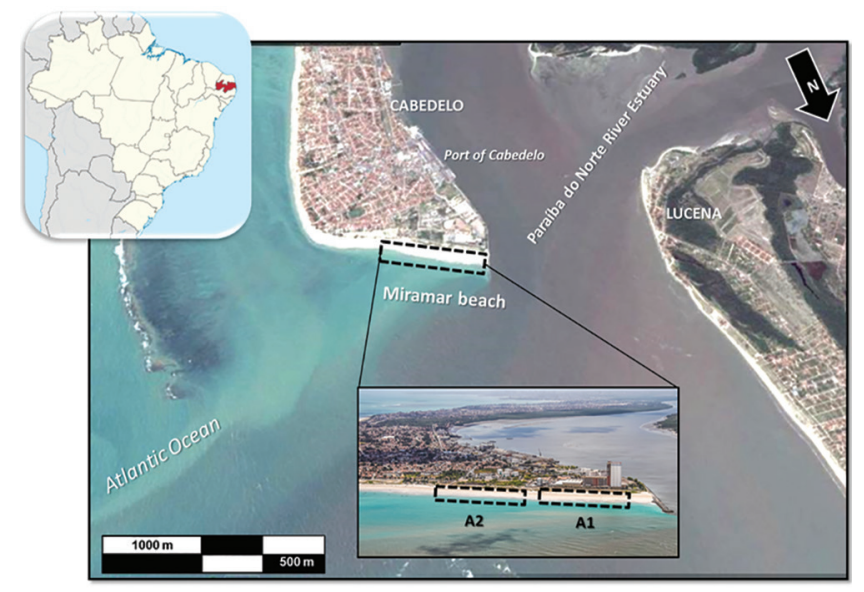

Fig. 1. Miramar beach in Cabedelo, Paraíba, northeast of Brazil. Two areas were highlighted (named as A1 and A2), located close to Paraíba River mouth (Source: Google Earth, accessed on 08 June 2016).

Statistical analysis. The two-way ANOVA was used to determine statistical differences in density (Ind.ha ${ }^{-1}$ ) and biomass $\left(\mathrm{g} \cdot \mathrm{ha}^{-1}\right)$ of fish species along the lunar cycle and beach areas. To avoid possible interference of rare species in the analyses, only species with frequency of occurrence $>$ $15 \%$ were included in analysis, according to Gauch's (1982) methodology. A priori data were transformed by Box-Cox (Box, Cox, 1964). When significant differences were found, the Tukey HSD comparison test was used a posteriori to 
detect the source of variation (Zar, 2010). All statistical analyzes were performed using Statistic ${ }^{\circledR} 7.0$ software (Statsoft) at a significance level of $P \leq 0.05$.

The redundancy analysis (RDA) was applied to determine the influence of water quality environmental variables on the density of species in the studied habitats during each phase of the moon, using CANOCO software 4.5, and the Monte- Carlo was used to determine which RDA axes and which environmental variables were significant (Braak, Smilauer, 2002).

\section{Results}

Composition, density and biomass of ichthyofauna. A total of 4,157 specimens were captured belonging to 49 species in 24 families, were caught from 48 samples conducted in Miramar beach (Tab. 1). The families with the highest number of species were Sciaenidae (7) and Haemulidae (6), followed by Carangidae (5), Engraulidade (4) and Ariidae (3). The other families presented lower wealth, with one or two species (Tab. 1). Among all fish species, Stellifer brasiliensis (Schultz, 1945) (Sciaenidae), Polydactylus virginicus (Linnaeus, 1758) (Polynemidae) and Anchoa tricolor (Spix, Agassiz, 1829) (Engraulidae) were the most abundant species with $60.5 \%$ of occurrence in samples (Tab. 1). Besides, Larimus breviceps Cuvier, 1830 also presented high biomass in absolute terms with $S$. brasiliensis and $P$. virginicus (Tab. 1). Also, Miramar Beach had an average density of 800 ind.ha $^{-1}$ and an average biomass of 1300 g.ha ${ }^{-1}$, as well as, the total mass captured in this study was $27,110 \mathrm{~g}$.

Lunar and spatial changes on ichthyofauna. In general, a number of species was similar according to the moon phase $(P \geq 0.05)$ (Tab. 2 and Fig. 2). On the other hand, mean total density was significant high in the weaning moon and low in the new moon $(P<0.05)$. Additionally, total density and biomass together showed differences for areas $(P<0.01$ and $P<0.05$, respectively) (Tab. 2 and Fig. 2).

The most representative species in frequency of occurrence showed statistical differences among moon phase and area for density and biomass (Tab. 2). The lunar phases showed significant influence for A. tricolor and Trachinotus falcatus (Linnaeus, 1758) $(P<0.05)$ in the new moon. Also, Anchovia clupeoides (Swainson, 1839) $(P<0.05)$ showed significant differences during the waning lunar phase on the beach of Miramar (Tab. 2).

Influence of physical-chemical parameters and lunar phase on ichthyofauna. Redundancy analysis (RDA) was applied to detect which of the environmental variables (temperature, turbidity, salinity, $\mathrm{pH}$ and conductivity) better explain the composition of fish assemblages among the most representative species, for the different lunar phases and collection areas. According to RDA results, the axes 1 explain $81.7 \%$ of Cumulative percentage variance of specie data and axes 2 explains $0.5 \%$, whereas for the ratio of species-environment axes 1 and 2 explains $99.5 \%$. The axes 1 showed a significant positive correlation for turbidity for species of group I (S. brasiliensis, Trachinotus goodei Jordan, Evermann, 1896, A. clupeoides, Chilomycterus spinosus (Linnaeus, 1758), Conodon nobilis (Linnaeus, 1758)). The group I was represented by species that occurred on the waning and new moon as demonstrated in the RDA analysis $(P<0.05)$ (Tab. 3 and Fig. 3). Additionally, the group II was formed by $P$. virginicus and Haemulopsis corvinaeformis (Steindachner, 1868) in the full moon phase (Fig. 3).

\section{Discussion}

The surf zone of Miramar beach has a great diversity of fishes, but also ecological importance for juveniles which living or passing especially in environments close to estuaries like in the beaches of Paraíba River mouth. The nursery contribution of surf zone probably determine the success of adult populations because survival of juveniles. Comparing the fish assemblage composition, the number of species caught in this study (49) was similar to that reported in the surf zone beaches, e.g. (40) False Bay, South Africa (Clarck et al.,1996), (55) Sepetiba bay southeastern Brazil (Pessanha, Araújo, 2003), (68) Goiana estuary, northeastern Brazil (Lacerda et al., 2014), (71) Mamanguape River estuary northeastern Brazil (Oliveira, Pessanha, 2014), (73) Southern New Jersey, U.S., and (83) Kyushu Island northwestern in Japan (Inui et al., 2010).

In fact, this study reinforces that the moon phase may strongly influence the composition and distribution of the ichthyofauna in the surf zone of the Miramar beach. The total density showed significant differences in the waning and new moon phases, but did not showed difference in the total biomass. In general, fish assemblages had lower densities in the new moon and higher in the weaning moon phase. The results of this study contrast with Ramos et al. (2011), who found a significant increase in the numbers of species, individuals and mass in mangrove intertidal creeks of the lower Goiana Estuary during the weaning and new moon, suggesting that these moon phases coincide with a higher number of species migrating into the mangrove. On the other hand, the spring tide (new moon) had significant low density in the Miramar beach. Perhaps, the wave action in the surf zone of Miramar has been as a determinant factor in the presence or absence of some component species of the ichthyofauna (Gondolo et al., 2011; Oliveira, Pessanha, 2014). Additionally, the diversity and abundance of the ichthyofauna species increase in sheltered and calm environments as mangroves (Inui et al., 2010; Oliveira, Pessanha, 2014). The Miramar beach may have a functional ecological connection with adjacent ecosystems, such Paraiba River estuary, which serves as passage routes or habitats, especially for juveniles fish (Inui et al., 2010). Thus, neap tides (weaning moon) increasing significantly the mean density of specimens which perhaps migrating from the mouth of Rio Paraiba estuary to the Miramar beach. 
Tab. 1. Abundance (n), biomass (g), and relative percentages of the specimens from the surf zone of Miramar Beach, in Cabedelo, Paraíba, northeast Brazil.

\begin{tabular}{|c|c|c|c|c|c|c|}
\hline \multirow[t]{2}{*}{ Family (24) } & \multirow[t]{2}{*}{ Family \% } & \multirow[t]{2}{*}{ Species (49) } & \multicolumn{2}{|c|}{ Abundance } & \multicolumn{2}{|c|}{ Biomass } \\
\hline & & & $\mathrm{n}$ & $\%$ & Weight (g) & $\%$ \\
\hline \multirow[t]{3}{*}{ Ariidae } & 6.12 & Cathorops agassizii (Eigenmann, Eigenmann, 1888) & 1 & 0.02 & 26 & 0.10 \\
\hline & & Cathorops spixii (Agassiz, 1829) & 12 & 0.29 & 789.11 & 2.91 \\
\hline & & Sciades proops (Valenciennes, 1840) & 1 & 0.02 & 163.60 & 0.60 \\
\hline \multirow[t]{5}{*}{ Carangidae } & 10.20 & Caranx latus Agassiz, 1831 & 167 & 4.02 & 469.50 & 1.73 \\
\hline & & Selene vomer (Linnaeus, 1758) & 54 & 1.30 & 237.78 & 0.88 \\
\hline & & Trachinotus carolinus (Linnaeus, 1766) & 11 & 0.26 & 85.27 & 0.31 \\
\hline & & Trachinotus falcatus (Linnaeus, 1758) & 45 & 1.08 & 463.42 & 1.71 \\
\hline & & Trachinotus goodei Jordan, Evermann, 1896 & 36 & 0.87 & 617.84 & 2.28 \\
\hline Clupeidae & 2.04 & Sardinella brasiliensis (Steindachner, 1879) & 6 & 0.14 & 16.84 & 0.06 \\
\hline Cynoglossidae & 2.04 & Symphurus tessellatus (Quoy, Gaimard, 1824) & 1 & 0.02 & 1.49 & 0.01 \\
\hline Diodontidae & 2.04 & Chilomycterus spinosus (Linnaeus, 1758) & 13 & 0.31 & 57.97 & 0.21 \\
\hline \multirow[t]{4}{*}{ Engraulidae } & 8.16 & Anchoa tricolor (Spix, Agassiz, 1829) & 547 & 13.16 & 1613.73 & 5.95 \\
\hline & & Anchovia clupeoides (Swainson, 1839) & 131 & 3.15 & 668.81 & 2.47 \\
\hline & & Cetengraulis edentulus (Cuvier, 1829) & 51 & 1.23 & 217.20 & 0.80 \\
\hline & & Lycengraulis grossidens (Spix, Agassiz, 1829) & 393 & 9.45 & 1313.47 & 4.84 \\
\hline Ephippidae & 2.04 & Chaetodipterus faber (Broussonet, 1782) & 4 & 0.10 & 57.51 & 0.21 \\
\hline Epinephelinae & 2.04 & Alphestes afer (Bloch, 1793) & 2 & 0.05 & 98.34 & 0.36 \\
\hline Exocoetidae & 2.04 & Exocoetus volitans Linnaeus, 1758 & 1 & 0.02 & 2.11 & 0.01 \\
\hline \multirow[t]{2}{*}{ Gerreidae } & 4.08 & Eucinostomus sp. & 6 & 0.14 & 111.68 & 0.41 \\
\hline & & Eugerres brasilianus (Cuvier, 1830) & 4 & 0.10 & 142.60 & 0.53 \\
\hline Gymnuridae & 2.04 & Gymnura micrura (Bloch, Schneider, 1801) & 1 & 0.02 & 58.40 & 0.22 \\
\hline \multirow[t]{6}{*}{ Haemulidae } & 12.24 & Conodon nobilis (Linnaeus, 1758) & 118 & 2.84 & 1186.44 & 4.38 \\
\hline & & Genyatremus luteus (Bloch, 1790) & 2 & 0.05 & 43.10 & 0.16 \\
\hline & & Haemulon aurolineatum Cuvier, 1830 & 9 & 0.22 & 49.25 & 0.18 \\
\hline & & Haemulon plumierii (Lacépède, 1801) & 6 & 0.14 & 141.19 & 0.52 \\
\hline & & Haemulon steindachneri (Jordan, Gilbert, 1882) & 3 & 0.07 & 97.65 & 0.36 \\
\hline & & Orthopristis ruber (Cuvier, 1830) & 17 & 0.41 & 602.16 & 2.22 \\
\hline Hemiramphidae & 2.04 & Hyporhamphus unifasciatus (Ranzani, 1841) & 26 & 0.63 & 197.17 & 0.73 \\
\hline \multirow[t]{2}{*}{ Labridae } & 4.08 & Halichoeres bivittatus (Bloch, 1791) & 1 & 0.02 & 6.89 & 0.03 \\
\hline & & Halichoeres poeyi (Steindachner, 1867) & 1 & 0.02 & 6.96 & 0.03 \\
\hline Labrisomidae & 2.04 & Labrisomus nuchipinnis (Quoy, Gaimard, 1824) & 1 & 0.02 & 2.50 & 0.01 \\
\hline Lutjanidae & 2.04 & Lutjanus synagris (Linnaeus, 1758) & 4 & 0.10 & 7.90 & 0.03 \\
\hline Mullidae & 2.04 & Pseudupeneus maculatus (Bloch, 1793) & 3 & 0.07 & 62.21 & 0.23 \\
\hline \multirow[t]{2}{*}{ Paralichthyidae } & 4.08 & Citharichthys spilopterus Günther, 1862 & 2 & 0.05 & 20.20 & 0.07 \\
\hline & & Etropus crossotus Jordan, Gilbert, 1882 & 1 & 0.02 & 27.10 & 0.10 \\
\hline Pristigasteridae & 2.04 & Chirocentrodon bleekerianus (Poey, 1867) & 13 & 0.31 & 29.76 & 0.11 \\
\hline \multirow[t]{2}{*}{ Polynemidae } & 4.08 & Polydactylus virginicus (Linnaeus, 1758) & 826 & 19.87 & 5331.76 & 19.67 \\
\hline & & Haemulopsis corvinaeformis (Steindachner, 1868) & 189 & 4.55 & 1214.26 & 4.48 \\
\hline \multirow[t]{7}{*}{ Sciaenidae } & 14.29 & Bairdiella ronchus (Cuvier, 1830) & 11 & 0.26 & 454.93 & 1.68 \\
\hline & & Larimus breviceps Cuvier, 1830 & 229 & 5.51 & 2818.24 & 10.39 \\
\hline & & Menticirrhus americanus (Linnaeus, 1758) & 12 & 0.29 & 355.40 & 1.31 \\
\hline & & Menticirrhus littoralis (Holbrook, 1847) & 11 & 0.26 & 267.61 & 0.99 \\
\hline & & Stellifer brasiliensis (Schultz, 1945) & 1142 & 27.47 & 6352.98 & 23.43 \\
\hline & & Stellifer rastrifer (Jordan, 1889) & 27 & 0.65 & 457.84 & 1.69 \\
\hline & & Umbrina coroides Cuvier, 1830 & 1 & 0.02 & 8.00 & 0.03 \\
\hline Scombridae & 2.04 & Scomberomorus cavalla (Cuvier, 1829) & 1 & 0.02 & 60.11 & 0.22 \\
\hline Syngnathidae & 2.04 & Syngnathus folletti Herald, 1942 & 1 & 0.02 & 0.50 & 0.01 \\
\hline \multirow[t]{2}{*}{ Tetraodontidae } & 4.08 & Sphoeroides greeleyi Gilbert, 1900 & 11 & 0.26 & 79.14 & 0.29 \\
\hline & & Sphoeroides testudineus (Linnaeus, 1758) & 2 & 0.05 & 23.83 & 0.09 \\
\hline
\end{tabular}


Tab. 2. Significant results of ANOVA for total density (ind. $\mathrm{ha}^{-1}$ ) and biomass (g.ha- $\left.{ }^{-1}\right)$ for most abundant fish species. Differences between lunar phase and area were determined by Tukey HSD test post hoc comparisons (italicized and bold letters indicate homogeneous groups). $\mathrm{Cr}$ crescent, $F u$ full, $W n$ waning, $N w$ new, ha: hectare; $* P<0.05$, $* * P$ $<0.01$.

\begin{tabular}{|c|c|c|c|}
\hline \multirow{2}{*}{ Variables } & \multicolumn{3}{|c|}{ Source of variance } \\
\hline & Lunar phase (1) & Area (2) & $(1 \times 2)$ \\
\hline Total ind.ha ${ }^{-1}$ & * Fu Cr Nw $\boldsymbol{W n}$ & $* *$ & NS \\
\hline g.ha $a^{-1}$ & NS & $*$ & NS \\
\hline Anchoa tricolor ind.ha- ${ }^{-1}$ & * Fu Cr Wn Nw & NS & NS \\
\hline g.ha- ${ }^{-1}$ & * Fu Cr Wn $N w$ & NS & NS \\
\hline Anchovia clupeoides ind.ha-1 & **Nw $\mathrm{Cr} \mathrm{Fu} \boldsymbol{W n}$ & NS & NS \\
\hline g.ha ${ }^{-1}$ & **Nw Cr Fu $\boldsymbol{W n}$ & NS & NS \\
\hline Conodon nobilis ind.ha ${ }^{-1}$ & NS & $* *$ & NS \\
\hline g.ha- ${ }^{-1}$ & NS & $* *$ & NS \\
\hline Chilomycterus spinosus ind.ha ${ }^{-1}$ & NS & $*$ & NS \\
\hline g.ha ${ }^{-1}$ & NS & $*$ & NS \\
\hline Larimus breviceps ind.ha- ${ }^{-1}$ & NS & $* *$ & NS \\
\hline g.ha ${ }^{-1}$ & NS & $* *$ & NS \\
\hline Polydactlus virginicus ind.ha ${ }^{-1}$ & NS & $* *$ & NS \\
\hline g.ha ${ }^{-1}$ & NS & $*$ & NS \\
\hline Trachinotus falcatus ind.ha-1 & *Wn $C r F u N w$ & $*$ & NS \\
\hline g.ha ${ }^{-1}$ & ${ }^{*} \mathrm{Wn} \mathrm{Cr}$ Fu Nw & NS & NS \\
\hline
\end{tabular}

On the most representative species, the new moon had a strong influence on the density and biomass of $A$. tricolor and $T$. falcatus, possibly because of higher tidal amplitudes while $A$. clupeoides was influenced by waning moon phase that represents lower tides in the Miramar beach. Only, Engraulidae and Carangidae family were impacted by lunar cycle and tidal range. Accordingly, Lacerda et al. (2014) the high abundance of fishes and crustaceans during the first and last quarter moon, which can be related to favorable conditions for occupying the habitat, with minor tidal dominance and major stability of the environmental variables, including tidal range.

During the new and waning moon was recorded the highest abundance for A. clupeoides in the sand beach during the dry season at dusk located at the mouth of Goiana estuary (Lacerda et al., 2014). The full and new moon phases had a strong influence on the variable number of individuals of $A$. clupeoides, possibly because of higher tidal amplitudes (Ramos et al., 2011). On the other hand, according to Lima et al. (2016), larvae of A. clupeoides were abundant in an estuary in Pernambuco, independent of the lunar phase. A. clupeoides is an Engraulidae, which typically forms large schoals and uses quieter environments for temporary shelter and feeding, both housed in estuaries and in the sandy beaches (Barreiros et al., 2004). This suggests that the behavior spatiotemporally of $A$. clupeoides is complex as a function of lunar cycles. In addition, it has a multiple factors study including reproduction and recruitment processes. The difficulty of setting a behavior pattern of the ichthyofauna according to the lunar cycle to the species can be explained by the high complexity of this issue (Quinn, Kojis 1981; Clark et al., 1996). The lunar cycle can simultaneously participate in many biological, physical and ecological processes, including variations of the tides that cause the migration of the ichthyofauna (Das et al., 2015).
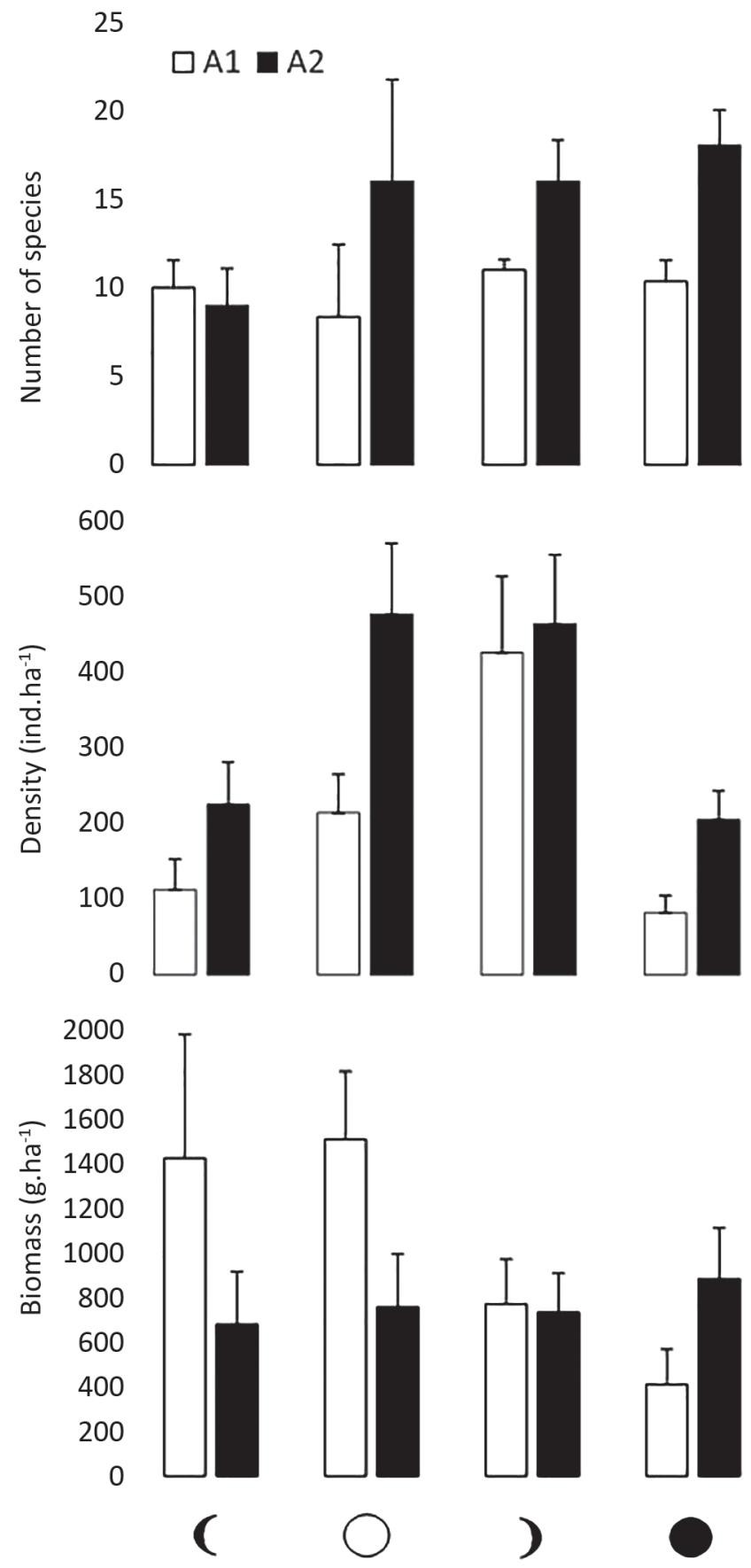

Fig. 2. Mean + Standard Error (SE) of number of species, total density (ind.ha ${ }^{-1}$ ) and biomass $\left(\mathrm{g}^{-h^{-1}}\right)^{-}$of fishes as a function of the lunar phases from left to right in the horizontal axes (crescent, full, weaning and new moon). 
Tab. 3. Summary of the results from redundancy analysis (RDA) relating environmental parameters to density of fish species caught. $* P<0.05$.

\begin{tabular}{|c|c|c|c|}
\hline & Axis 1 & Axis 2 & p-value \\
\hline \multicolumn{4}{|l|}{ Enviromental - Abundance } \\
\hline Eigenvalues & 0.817 & 0.005 & - \\
\hline Species-Enviromental correlations & 0.910 & 0.961 & - \\
\hline \multicolumn{4}{|l|}{ Cumulative of $\%$ variance } \\
\hline Of species Data & 81.7 & 82.2 & - \\
\hline Of specie-enviromental relations & 98.9 & 99.5 & - \\
\hline \multicolumn{4}{|l|}{ Correlations with enviromental variables: } \\
\hline Water temperature $\left({ }^{\circ} \mathrm{C}\right)$ & -0.4134 & -0.2822 & 0.1087 \\
\hline Turbidity (NTU) & 0.4380 & 0.1463 & $0.0169 *$ \\
\hline Salinity & -0.5095 & 0.1776 & 0.4525 \\
\hline$p H$ & 0.3455 & -0.1631 & 0.2435 \\
\hline Conductivity & -0.1573 & -0.1674 & 0.3906 \\
\hline
\end{tabular}

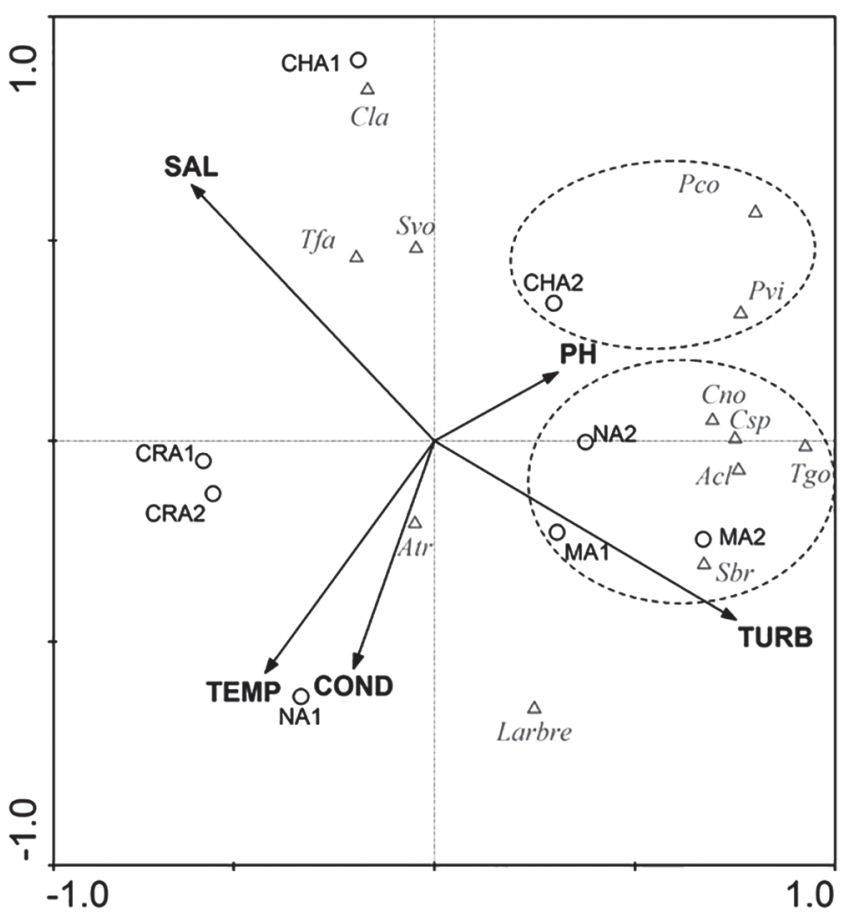

Fig. 3. Redundancy analysis (RDA) for the density (ind. $\mathrm{ha}^{-1}$ ) of the most representative species in Miramar Beach, Cabedelo. $(\mathrm{TEMP}=$ temperature; $\mathrm{SAL}=$ salinity; $\mathrm{TURB}=$ surbidity; $\mathrm{COND}=$ conductivity e $\mathrm{PH}=$ hidrogen potential. $($ Atr $=$ Anchoa tricolor; Acl = Anchovia clupeoides; Cla $=$ Caranx latus $;$ Cs $p=$ Cathorops spixii; Cno $=$ Conodon nobilis; $P c o=$ Haemulopsis corvinaeformis; $P v i=$ Polydactylus virginicus; Larbre $=$ Larimus breviceps; Svo $=$ Selene vomer; $\mathrm{Sbr}=$ Stellifer brasiliensis; Tfa $=$ Trachinotus falcatus; Tgo = Trachinotus goodei). Lunar phase and sampling areas (CRA1 - crescent/ area 1; CRA2 -crescent/ area 2; NA1 -New/ area 1; NA2 -New / area 2; CHA1 - Full/ area 1; CHA2 -Full/ area 2; MA1 -Waning/ area 1; MA2 -Waning/ area 2).
Anchoa tricolor had dominance in the almost all moon phases, except for full moon in this study. The biomass was significant for new and waning moon phases. It is very important mentioning that this species did not any information about lunar cycle and density in the surf zone in another study. Corroborating with the present study, A. tricolor, showing that it is a resident of the surf zone, similar to the study by Santana et al. (2013), when it was captured in all samples, both in the dry season in the rainy season. A. tricolor was the most frequent in a study carried out at the surf zone in the Bay of Sepetiba area in Rio de Janeiro (Pessanha, Araújo, 2003). Pereira et al. (2014), demonstrated that this species is the most abundant in two distinct beaches.

The high density of $T$. falcatus in the spring tides (new and full) in the Miramar beach suggests that this carangidae tolerate exposure to waves and remain in place (Vasconcellos et al., 2007). Additionally, the continuous action of the waves on the sandy bottom, although stressful, provides a great amount of food, allowing the capture of prey in this environment by species that can adapt to these conditions (Clark et al., 1996). On the opposite way, according to Menegassi del Favero, Dias (2013), the capture of T. goodei and T. falcatus was considered accidental in a study carried out during a year in a surf zone on Cardozo Island in the Southeast. Corroborating this present study, Trachinotus $s p$. were caught in abundance on a beach in Santa Catarina (Barreiros et al., 2004).

At the Miramar beach, area A2 showed significantly higher total densities and biomass. Among all most representative species had significant differences $C$. nobilis, L. breviceps, C. spinosus, P. virginicus and T. falcatus (Tab. 2). The Engraulidae species (A. tricolor and A. clupeoides) did not showed differences between areas. The A2 is located on a beach portion in which was observed the presence of artisan fishermen. On the other hand, A1 is near the mouth of the Paraiba River, adjacent to the dike Cabedelo, which is the point of surfing practice because the waves exposure. The fact of the A1 have lower densities and biomass compared to A2 may be related to wave exposure factor. Spatial differences in the structure of fish assemblages are often demonstrated in studies associating ichthyofauna with beach morphodynamics (Gondolo et al., 2011; Oliveira, Pessanha, 2014), partially chasing the ichthyofauna (Romer, 1990; Gaelzer, Zalmon, 2003; Vasconcellos et al., 2007; Inui et al., 2010; Oliveira, Pessanha, 2014), since the height of the tide has strong influence on the ichthyofauna of the composition of surf zone (Pereira et al., 2014).

In general, salinity, temperature and turbidity are the variables that influence the distribution of several juvenile species of the ichthyofauna (Whitfield, 1994). Although the importance of each environmental factor depends and differentiates according to the species (Blaber, Blaber, 1980; Ramos et al., 2011).

In this study, turbidity significantly influenced fish density at Miramar Beach. It is also possible to observe an 
association of two groups influenced (Fig. 3). In general, the increase of the turbidity in Miramar beach were recorded on the waning moon and clearer waters, with less turbidity, on the crescent and full moon. The RDA showed that the turbidity was determinant for the presence of $A$. clupeoides, S. brasiliensis, T. goodei, Cnobilis and C. spinosus on the waning and new moon phases, also $P$. virginicus and $H$. corvinaeformis in the full moon $(P=0.0169)$, although this behavior also needs to be investigated in a annual time scale to assess the effects of seasonality (Clark et al., 1996). The waning moon had significantly higher values for its turbidity according to the variance analysis, confirming thus the relationship between the waning phase and higher turbidity for both capture areas (A1 and A2). Corroborating these results, the highest turbidity was also a determining factor in the abundance of ichthyofauna in Australia (Blaber et al., 1995), Kuwait City in the Arabian Peninsula (Abouseedo et al., 1990) and South Africa (Cyrus, Blaber, 1987). Additionally, turbidity can bring ecological advantages for juvenile fish, as it serves as a cover against predators, but also provides food for the ichthyofauna of the surf zone (Cyrus, Blaber, 1987; Abou-Seedo et al., 1990; Menegassi del Favero, Dias, 2013). On the other hand, a high turbidity can cause as much physiological stress to the fish, as to cause a high availability of food in the environment (Gondolo et al., 2011).

\section{Acknowledgments}

We particularly thank Jonas de Assis Almeida Ramos for their invaluable assistance with fieldwork, species identification and statistical analysis. We wish to thank the members of the Grupo de Ecologia de Ecossistemas Marinhos (Maíra de Souza, Bruno Soares, Lucas Matheus, Amanda Kelly, Amanda Soares, Paulo Victor, Ana Luisa, Dionarte Ferreira, Angela Regina, Juninho Franco, Andreza Nascimento, Ana Carla, Ana Santos, Felipe Kuroski, , João Assunção, Ingrid Elvira, Rosy Santos, Andrezza Dantas, Anna Luiza, Larissa Kathleen, Amaralina Meireles, Matheus Oliveira, Dayllana Ellen, Nicole dos Santos, Iago Senna, Jennifer Freire, Victor Gabriel), Instituto Federal de Educação, Ciência e Tecnologia da Paraíba (IFPB - Campus Cabedelo) and Grupo de Aquicultura, Biotecnologia e Sustentabilidade (GABS), Instituto Federal de Educação, Ciência e Tecnologia da Paraíba (IFPE - Campus Vitória de Santo Antão).

\section{References}

Able KW, Wuenschel MJ, Grothues TM et al. Do surf zones in New Jersey provide "nursery" habitat for southern fishes? Environ Biol Fish. 2013, 96(5):661. Available from: https:// doi.org/10.1007/s10641-012-0056-8

Abou-Seedo F, Clayton DA, Wright JM. Tidal and turbidity effects on the shallow-water fish assemblage of Kuwait Bay. Mar Ecol Prog Ser. 1990; 65:213-23.
Barletta M, Barletta-Bergan A, Saint-Paul U, Hubold G. The role of salinity in structuring the fish assemblages in a tropical estuary. J Fish Biol. 2005; 66(1):45-72.

Barreiros JP, Figna V, Hostim-Silva M, Santos RS. Seasonal changes in a sandy beach fish assemblage at Canto Grande, Santa Catarina, South Brazil. J Coastal Res. 2004; 20(3):862-70.

Blaber SJM, Blaber TG. Factors affecting the distribution of juvenile estuarine and inshore fish. J Fish Biol. 1980; 17(2):143-62.

Blaber SJM, Brewer DT, Salini JP. Fish communities and the nursery role of the shallow inshore waters of a tropical bay in the Gulf of Carpentaria, Australia. Estuarine, Coastal Shelf Sci. 1995; 40(2):177-93.

Box GEP, Cox DR. An analysis of transformation. J R Stat Soc B. 1964; 26(2):211-52.

Ter Braak CJF, Smilauer P. CANOCO Reference Manual and CanoDraw for Windows User's Guide: Software for Canonical Community Ordination (Version 4.5). Ithaca, NY: Microcomputer Power. 2002. Available from: www.canoco.com

de Bruyn AMH, Meeuwing JJ. Detecting lunar cycles in marine ecology: periodic regression versus categorical ANOVA. Mar Ecol Progr Ser. 2001; 214:307-10.

Carpenter KE. The living marine resources of the Western Central Atlantic. Volume 2: Bony fishes part 1 (Acipenseridae to Grammatidae). Rome: FAO; 2002a. (FAO Species Identification Guide for Fishery Purposes and American Society of Ichthyologists and Herpetologists Special Publication; No. 5).

Carpenter KE. The living marine resources of the Western Central Atlantic. Volume 3: Bony fishes part 2 (Ophistognathidae to Molidae), sea turtles and marine mammals. 2002b. Rome: FAO; 2002a. (FAO Species Identification Guide for Fishery Purposes and American Society of Ichthyologists and Herpetologists Special Publication; No. 5).

Clark BM, Bennett BA, Lamberth SJ. Factors affecting spatial variability in seine net catches of fish in the surf zone of False Bay, South Africa. Mar Ecol Progr Ser. 1996; 131:17-34.

Cowley PD, Whitfield AK, Bell KNI. The surf zone ichthyoplankton adjacent to an intermittently open estuary, with evidence of recruitment during marine overwash events. Estuarine, Coastal Shelf Sci. 2001; 52(3):339-48.

Cyrus DP, Blaber SJM. The influence of turbidity on juvenile marine fish in the estuaries of Natal, South Africa. Cont Shelf Res. 1987; 7(11-12):1411-16.

Das D, Pal S, Braumik U, Paria T, Mazundar D, Pal. The optimum fishing day is based on moon. Int J Fish Aquat Stud. 2015; 2(4):304-09.

Eschmeyer WN, Fricke R, van der laan R. editors. Catalog of fishes: genera, species, references [internet]. San Francisco: California Academy of Science; 2017. Available from: http:// researcharchive.calacademy.rg/research/Ichthyology/catalog/ fishcatmain.asp

Figueiredo JL. Manual de peixes marinhos do sudeste do Brasil. I. Introdução cações, raias e quimeras. São Paulo: Museu de Zoologia da USP; 1977.

Figueiredo JL, Menezes NA. Manual de peixes marinhos do sudeste do Brasil. II. Teleostei (1). São Paulo: Museu de Zoologia da USP; 1978. 
Figueiredo JL, Menezes NA. Manual de peixes marinhos do sudeste do Brasil. III. Teleostei (2). São Paulo: Museu de Zoologia da USP; 1980.

Figueiredo JL, Menezes NA. Manual de peixes marinhos do sudeste do Brasil. VI. Teleostei (5). São Paulo: Museu de Zoologia da USP; 2000.

Froese R, Pauly D. editors. FishBase. Penang (MA), Rome: FAO; 2016. Available from: www.fishbase.org

Gaelzer LR, Zalmon IR. The influence of wave gradient on the ichthyofauna of southeastern Brazil: Focusing the community structure in surf-zone. J Coastal Res. 2003; 35:456-62.

Gauch HG. Multivariate analysis in community ecology. New York, NY: Cambridge University Press; 1982.

Goldman B, Greg S, Frank T. Fish eggs and larvae over a coral reef: abundance with habitat, time of day and moon phase. In: Baker JT, Carter RM, Sammarco PW, Stark KP, editors. Proceedings of the inaugural Great Barrier Reef Conference. 1983; 34(4):203-211.

Gondolo GF, Mattox GMT, Cunningham PTM. Aspectos ecológicos da ictiofauna da zona de arrebentação da praia de Itamambuca, Ubatuba, SP. Biota Neotrop. 2011; 11(2):183-92.

Harrison TD, Whitfield AK. Temperature and salinity as primary determinants influencing the biogeography of fishes in South African estuaries. Estuarine, Coastal Shelf Sci. 2006; 66(12):335-45.

Inui R, Nishida T, Onikura N, Eguchi K, Kawagishi M, Nakatani M, Oikawa S. Physical factors influencing immature-fish communities in the surf zones of sandy beaches in northwestern Kyushu Island, Japan. Estuarine, Coastal Shelf Sci. 2010; 86(3):467-76.

Lacerda CHF, Barletta M, Dantas DV. Temporal patterns in the intertidal faunal community at the mouth of a tropical estuary. J Fish Biol. 2014; 85(5):1571-602.

Laroche J, Baran E, Rasoanandrasana NB. Temporal patterns in a fish assemblage of a semiarid mangrove zone in Madagascar. J Fish Biol. 1997; 51(1):3-20.

Lima ARA, Barletta M, Costa MF, Ramos JAA, Dantas DV, Melo PAMC, Justino AKS, Ferreira GVB. Changes in the composition of ichthyoplankton assemblage and plastic debris in mangrove creeks relative to moon phases. J Fish Biol. 2016; 89(1):619-40.

McDowall RM. Lunar rhythms in aquatic animals: A general review. Tuatara. 1969; 17(3):133-44.

Menegassi del Favero JM, Dias JF. Spatio-temporal variation in surf zone fish communities at Ilha do Cardoso State Park, São Paulo, Brazil. Lat Am J Aquat Res. 2013; 41(2):239-53.

Oliveira REMCC, Pessanha ALM. Fish assemblages along a morphodynamic continuum on three tropical beaches. Neotrop ichthyol. 2014;12(1):165-75. Available from: http://dx.doi. org/10.1590/S1679-62252014000100018
Pereira HH, Neves LM, Costa MR, Araújo FG. Fish assemblage structure on sandy beaches with different anthropogenic influences and proximity of spawning grounds. Mar Ecol. 2014; 36(1):16-27. Available from: http://doi:10.1111/maec.12113

Pessanha ALM, Araújo FG. Spatial, temporal and diel variations of fish assemblages at two sandy beaches in the Sepetiba Bay, Rio de Janeiro, Brazil, Estuarine, Coastal Shelf Sci, 2003; 57(2003):817-28.

Quinn NJ, Kojis BL. The lack of changes in nocturnal estuarine fish assemblages between new and full moon phases in Serpentine Creek, Queensland. Environ Biol Fishes. 1981; 6(2):213-18.

Ramos JAA, Barletta M, Dantas DV, Costa, MF. Seasonal and spatial ontogenetic movements of Gerreidae in a Brazilian tropical estuarine ecocline and its application for nursery habitat conservation. J Fish Biol. 2016; 89(1):696-712.

Ramos JAA, Barletta M, Dantas DV, Lima ARA, Costa MF. Influence of moon phase on fish assemblages in estuarine mangrove tidal creeks. J Fish Biol. 2011; 78(1):344-54.

Richards WJ. Early stages of Atlantic fishes: an identification guide for the Western Central North Atlantic. Volume I and Volume II. Boca Raton: CRC Press; 2006.

Romer GS. Surf zone fish community and species response to a wave energy gradient. J Fish Biol. 1990; 36(3):279-87.

Rooker JR, Dennis GD. Diel, lunar and seasonal changes in a mangrove fish assemblage off southwestern Puerto Rico. Bull Mar Sci. 1991; 49(3):684-98.

Santana FMS, Severi W, Feitosa CV, Araujo ME. The influence of seasonality on fish life stages and residence in surf zones: a case of study in a tropical region. Biota Neotrop. 2013; 13 (3):181-92.

Sparre P, Venema SC. Introduction to tropical fish stock assessment. Part 1. Manual. FAO Fisheries Technical Paper 360, 1998; 333-42.

Taylor MH. Lunar synchronization of fish reproduction. Trans Am Fish Soc. 1984; 113(4):484-93.

Vasconcellos RM, Santos JNS, Silva MA, Araújo FG. Efeito do grau de exposição às ondas sobre a comunidade de peixes juvenis em praias arenosas do Município do Rio de Janeiro, Brasil. Biota Neotrop. 2007, 7(1):93-100.

Watt-Pringle P, Strydom NA. Habitat use by larval fishes in a temperate South African surf zone. Estuarine, Coastal Shelf Sci. 2003; 58(4):765-74.

Whitfield AK. Abundance of larval and $0+$ juvenile marine fishes in the lower reaches of three southern African estuaries with differing freshwater inputs. Mar Ecol Prog Ser. 1994; 105:257-67.

Zar JH. Biostatistical analysis. 5th ed. Upper Saddle River (NJ): Prentice Hall; 2010. 